
15 (1987) 95
J. Perinat. Med.

\section{Fenoterol depot and fenoterol in premature uterine contractions - a multicentric double-blind comparative study}

\author{
Wolfgang Müller-Holve1, Mark Hermer ${ }^{2}$, Friedrich Karl Klöck ${ }^{3}$, Manfred \\ Kreis $^{2}$, Herbert Brehm ${ }^{4}$, Hubert Elser ${ }^{5}$, Hans-Jürgen Kitschke ${ }^{6}$, Dietrich Berg ${ }^{7}$, \\ Volker Harms ${ }^{3}$, and Dieter Hägele ${ }^{7}$
}

\begin{abstract}
${ }^{1}$ Department of Obstetrics and Gynecology, Clinic of Ingolstadt, ${ }^{2}$ Medical Department, Boehringer Ingelheim KG, ${ }^{3}$ Hospital "St. Elisabeth", Cologne, ${ }^{4}$ Women's Hospital of Cologne-Holweide, ${ }^{5}$ Department of Obstetrics and Gynecology, University Clinic of Munich, ${ }^{6}$ Department of Obstetrics and Gynecology, University Clinic Hamburg-Eppendorf, ${ }^{7}$ Municipal Hospital of Amberg, West Germany
\end{abstract}

\section{Introduction}

The prevention of premature uterine contractions and thus premature birth has been one of the most important problems of perinatal medicine for many years $[1,3,4,5,7]$. A relevant and reproducible tocolysis with clinically demonstrable effect has only been possible since the development of relatively selective beta 2 mimetics. This has been documented especially for fenoterol in large number of studies in the last 15 years [14].

Oral therapy with fenoterol is gernerally carried out with $5 \mathrm{mg}$ Partusisten tablets administered at time intervals of three to six hours. To improve compliance, a fenoterol depot form was developed in order to make possible successful oral therapy with an eight-hour (or night) pause for taking the preparation.

Results of first clinical experience with such a depot form are already available $[2,8,11,13]$. In this study a randomization was carried out at six centers in accordance with valid criteria, and the effects and side effects of a fenoterol depot preparation with delayed release of active substance (designated as fenoterol depot) and a fenoterol preparation with undelayed release of active substance (designated as fenoterol) randomized in accordance with valid criteria and with the use of a double-blind method were compared with an approximately equal overall dose over a period of 360 minutes at six centers.

\section{Patients and methods}

The study included 131 hospitalized patients between the 18th and 38th week of pregnancy (mean: 32.6) in which tocolytic treatment was indicated because of premature uterine contractions. Sixty-six of these patients received fenoterol depot and 65 patients received fenoterol.

The patients were allocated to one or the other group according to a valid randomization plan. The patients in the fenoterol depot group received three fenoterol capsules* containing fenoterol with a total dose of $21 \mathrm{mg}$ only at the first administration. The second and third applications were made with placebos.

\footnotetext{
* Partusisten Depot Perlongette ${ }^{\circledR}$, Boehringer Ingelheim
} 
In the fenoterol group, a capsule* containing $7.5 \mathrm{mg}$ fenoterol and two placebos were administered at each of the three applications, so that in all $22.5 \mathrm{mg}$ of fenoterol were administered.

Fenoterol was used in the form of small film tablets in an immediately dissolvable gelatine capsule. A fenoterol depot capsule consisted of four such film tablets, one $2.5 \mathrm{~g}$ tablet which released fenoterol without delay, and the three remaining $1.5 \mathrm{mg}$ tablets which released the fenoterol continuously and slowly. The fenoterol capsule consisted of three $2.5 \mathrm{mg}$ film tablets. As with the conventional Partusisten tablet on the market, it released fenoterol without delay. The placebo capsule was identical in appearance and taste with the two true preparations, but did not contain any fenoterol.

An initial situation which was comparable for the two groups was attained in a clinically proved fashion by intravenous tocolysis with Partusiten in a dosage of $1-3 \mu \mathrm{g} / \mathrm{min}$ over the duration of 30 minutes. The duration of the investigation was 360 minutes. The corresponding preparations were administered orally 5 , 120 and 240 minutes after beginning of infusion.

For comparative evaluation of fenoterol depot with fenoterol, duration of contraction, frequency of uterine contractions per $10 \mathrm{~min}$ (both in accordance with the cardiotocogram (CTG)), subjective intensity of uterine contractions (reported by the patient as none, moderate, severe, very severe and rated as $0,1,2,3$ respectively), maternal pulse rate (MPRV), systolic and diastolic blood pressure, fetal pulse rate (FPR, in accordance with the CTG) as well as the tocolytic efficacy and tolerance (both appraised by the treating physician) were registered for comparison of fenoterol depot with fenoterol. In addition, the side effects of the two preparations were documented.

* Analogous to the Partusisten ${ }^{\circledR}$ tablet with regard to release of fenterol.
The duration of contraction was evaluated according to two criteria: as "mean duration of contraction per overall group" and as "mean duration of the single contraction". In the former, all contraction times of all patients investigated including those with a value " 0 " (no contraction at the time of measurement) was added together for each of the defined measurement times and averaged over the total number of patients of the respective group. In the second criterion, only those patients of the group in whom measurable contractions were present at the fixed measurement time were considered. Prior value (before the beginning of infusion), 30 minutes after the beginning of infusion (end of infusion), 90 minutes (second oral administration), 210 minutes (third oral administration) and 330 minutes (end of the trial) after the end of infusion were determined as measurement times. Since contractions were not present at all five measurement times in one and the same patient, the corresponding mean values were mainly not obtained in the same patients. In order to be able to compare the mean value of the respective measurement time with the pretrial mean value in the same patients, only those patients with measurable uterine contraction were considered for the calculation of the pretrial mean value (in whom contractions had been present at the respective measurement times. The value obtained at each of the four measurement times after the end of infusion was compared with the corresponding pretrial value. The values for the frequency of uterine contractions " for ten minutes were extrapolated to the number of uterine contractions per hour.

The results from the two investigative group were compared with each other and evaluated statistically by means of the chi square test for the strength of uterine contractions and the side effects.

In the fenoterol depot group, the data of 60 out of the total of 66 and in the fenoterol group the data of 56 or 58 out of the 65 patients included in this study could be evaluated from a statistical point of view. All patients were registered with regard to the side effects. 


\section{Results}

\subsection{Tocolytic effect}

Mean duration of contraction per overall group: In the fenoterol depot group, the mean duration of contraction under the 30-minute Partusisten infusion fell from $58.8 \mathrm{sec}$ to $12.8 \mathrm{sec}$ or by $78.2 \%$ of the initial value (figure 1 ). Up to the end of the investigation, this lowering under the single effect of the single dose of fenoterol depot was maintained within a small range of variation with a maximum decrease to $9.0 \mathrm{sec}$ $(84.7 \%)$ and was only $9.8 \mathrm{sec}$ at the end of the investigation ( $83.3 \%$ under the pretrial value). The mean duration of contraction fell in the fenoterol group from $58.5 \mathrm{sec}$ to $11.9 \mathrm{sec}$ ( $79.9 \%$ reduction) (figure 1 ) under the 30 -minute Partusisten infusion and remained at this low level with a maximum decrease to $9 \mathrm{sec}$ $(84.4 \%)$. At the end of the investigation, the mean duration of contraction was $10.7 \mathrm{sec}$ (81.7\% lowering compared to the initial value).

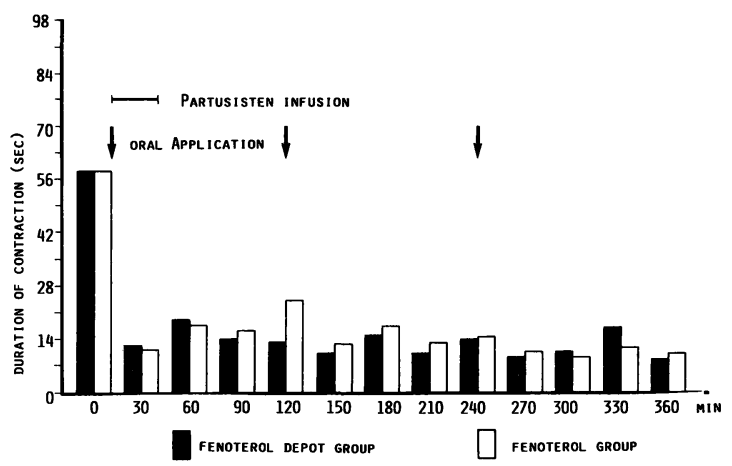

Figure 1. Influence of the initial Partusisten infusion and the two fenoterol test preparations on the mean duration of contraction per overall group (explanation in the text).

Mean duration of the individual contraction: In the fenoterol depot group, the mean duration of the individual contraction after the end of the initial 30-minute Partusisten infusion fell by $42.9 \%$ from $73.7 \mathrm{sec}$ to $42.1 \mathrm{sec}$. It remained at a low level with a maximum of $49.5 \mathrm{sec}(90$ minutes after the end of the infusion) up to the end of the observation period without a fresh administration of fenoterol. The mean duration of the individual contraction was reduced by $28.5 \%$ from $68 \mathrm{sec}$ to $48.6 \mathrm{sec}$ in the fenoterol group at the end of infusion. In the further course of the investigation under oral administration alone, it rose to values between $66.6 \mathrm{sec}$ and $56.0 \mathrm{sec}$, but remained 5.1 to $16.7 \%$ below the respective pretrial value (figure 2, table I).

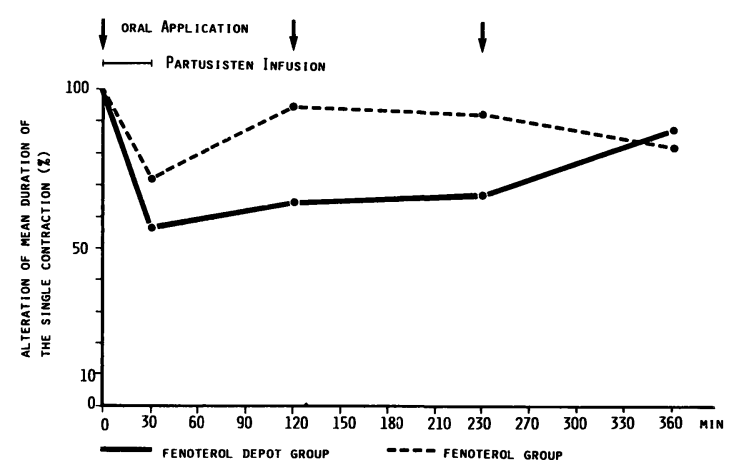

Figure 2. Percentage alteration of the mean duration of the single contraction under influence of the initial Partusisten infusion and the two fenoterol test preparations (explanation in the text).

The maximum difference $(25.7 \%)$ of the mean duration of the individual contraction between the fenoterol depot group and the fenoterol group was attained 90 minutes after the end of infusion. It was $14.1 \% 330$ minutes after the end of infusion (table I). The mean duration of contraction in the fenoterol depot group always demonstrated a higher reduction compared to the fenoterol group. Neither for a mean duration of contraction per overall group nor for the mean duration of the individual contraction was there a statistically significant difference between the groups for the six measurement times considered.

Frequency of uterine contractions: The level of 14.2 uterine contractions per hour present in the fenoterol depot group before the beginning of the 30-minute Partusisten infusion could be lowered to a mean value of 2.8 contractions per hour $(80.3 \%$ of the initial value) after the end of the infusion. Under the action of a single dose of fenoterol depot alone, the frequency of 
Table I. Reduction of the mean duration of the individual contractions compared to the respective previous values (before the beginning of the Partusisten infusion) in the fenoterol depot group and fenoterol group at different times at the end of the initial Partusisten infusion with comparison of the two preparations.

\begin{tabular}{|c|c|c|c|c|c|c|c|}
\hline & $\begin{array}{l}\text { Mean dura- } \\
\text { tion of the } \\
\text { single con- } \\
\text { traction (sec) } \\
\text { in fenoterol } \\
\text { group }\end{array}$ & $\begin{array}{l}\text { Differ- } \\
\text { ence } \\
\%\end{array}$ & $\mathrm{n}$ & $\begin{array}{l}\text { Mean dura- } \\
\text { tion of the } \\
\text { single con- } \\
\text { traction }(\mathrm{sec}) \\
\text { in fenoterol } \\
\text { depot group }\end{array}$ & $\begin{array}{l}\text { Differ- } \\
\text { ence } \\
\%\end{array}$ & $\mathrm{n}$ & $\begin{array}{l}\text { Difference between } \\
\text { the actual duration } \\
\text { of contraction be- } \\
\text { tween the fenoterol } \\
\text { group and the fe- } \\
\text { noterol depot group }\end{array}$ \\
\hline \multirow[t]{2}{*}{ before infusion } & 68.0 & & & 73.7 & & & \\
\hline & & 28.5 & 15 & & 42.9 & 18 & \\
\hline end of infusion & 48.6 & & & 42.1 & & & 13.4 \\
\hline \multirow[t]{2}{*}{ before infusion } & 70.2 & & & 77.5 & & & \\
\hline & & 5.1 & 20 & & 36.1 & 15 & \\
\hline $\begin{array}{l}90 \text { min after the } \\
\text { end of infusion }\end{array}$ & 66.6 & & & 49.5 & & & 25.7 \\
\hline \multirow[t]{2}{*}{ before infusion } & 62.1 & & & 69.5 & & & \\
\hline & & 7.6 & 14 & & 33.2 & 17 & \\
\hline $\begin{array}{l}210 \text { min after the } \\
\text { end of infusion }\end{array}$ & 57.4 & & & 46.4 & & & 19.2 \\
\hline \multirow[t]{2}{*}{ before infusion } & 67.2 & & & 55.3 & & & \\
\hline & & 16.7 & 11 & & 13.0 & 12 & \\
\hline $\begin{array}{l}330 \text { min after the } \\
\text { end of infusion }\end{array}$ & 56.0 & & & 48.1 & & & 14.1 \\
\hline
\end{tabular}

uterine contractions fell to 1.3 contractions per hour $(90.8 \%$ of the initial value) by the end of the investigation (figure 3 ).

A mean frequency of uterine contractions of 13.0 contractions per hour previously present in the fenoterol group was reduced to a mean frequency of 1.5 contractions per hour $(88.5 \%$ of the initial value) under the 30-minute Partusisten infusion. In the further course, there was no noteworthy elevation of the frequency of uterine contractions (figure 3). This was 1.6 contractions per hour (reduction by $87.7 \%$ of the initial value) at the end of the investigation.

There was no significant difference in favor of the fenoterol depot for the measurement times up to $300 \mathrm{~min}$ after the end of the 30 -minute infusion, and a significant difference at the $10 \%$ level at the end of the investigation.

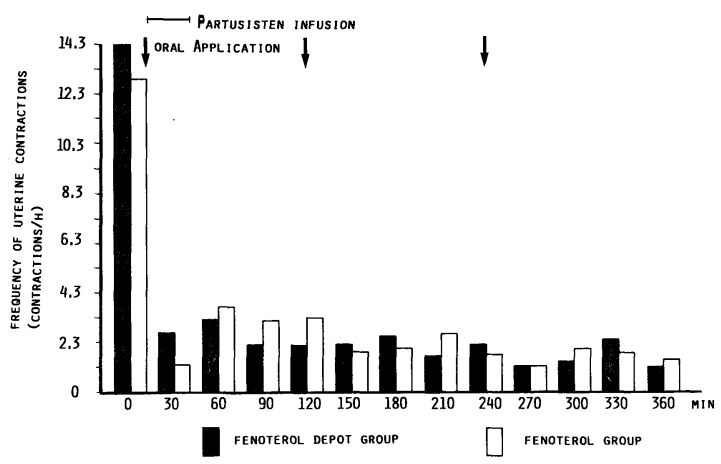

Figure 3. Effect of the initial Partusisten infusion and the two fenoterol test preparations on frequency of uterine contractions.

Intensity of uterine contractions: Before the beginning of the 30-minute Partusisten infusion, the mean intensity of labor pains evaluated subjectively by the patients was 1.4 in both 
groups. The intensity of uterine contractions was reduced immediately after the end of infusion in the two groups to values of 0.3 to 0.4 and remained at values between 0.2 and and 0.3 up to the end of the investigation.

\subsection{Effects on the cardiovascular system in mother and fetus}

Maternal pulse rate (MPR): The mean MPR in the fenoterol depot group was 99.6 beats/ min at the end of the Partusisten infusion (pretrial value 91.3 beats $/ \mathrm{min}$ ). It reached a maximum of 104.6 beats/min $150 \mathrm{~min}$ after the end of infusion and was at 101.6 beats $/ \mathrm{min}$ at the end of investigation (figure 4). In the fenoterol group, the mean MPR immediately after the 30-minute Partusisten infusion rose from an initial value of 90.3 to 103.3 beats $/ \mathrm{min}$. Under the further oral application, the mean MPR remained in this range with a maximum of 105.6 beats/min (figure 4). For the time 30 minutes after the end of infusion, there was a statistically significant difference between the two groups at the $5 \%$ level. There was a higher increase of MPR in the fenoterol group than in the fenoterol depot group. There was no significant difference for all other measurement times.

In both groups, the systolic blood pressure did not show any clinically relevant alterations during treatment with the two preparations. The mean value was between 116.9 and 118.4 $\mathrm{mmHg}$ (pretrial value $119.4 \mathrm{mmHg}$ ) in the fenoterol depot group; in the fenoterol group, it was between 114.0 and $117.5 \mathrm{mmHg}$ (pretrial value 115.9) (figure 5). In the two groups, the diastolic blood pressure showed a constant course within a narrow range of variation with a slight tendency to lowering compared to the pretrial value. The lowest mean value was 64.4 $\mathrm{mmHg}$ in the fenoterol depot group and the highest mean value was $67.9 \mathrm{mmHg}$ (pretrial value $70.8 \mathrm{mmHg}$ ). For the fenoterol group, the corresponding values were $61.8 \mathrm{mmHg}$ and $67.6 \mathrm{mmHg}$ (preterial value $63.9 \mathrm{mmHg}$ ). There was no significant difference at the $10 \%$ level between the two groups for the systolic blood pressure, and in the case of the diastolic blood pressure there was a significant difference at the $10 \%$ level only for the fifth of the six measurement times (figure 6).

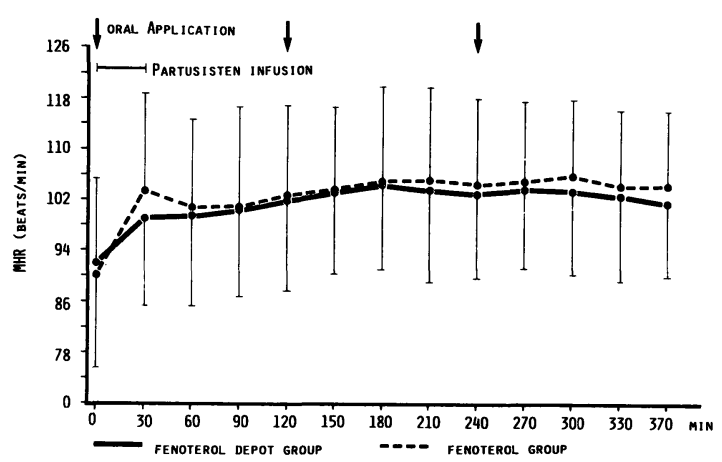

Figure 4. Behavior of maternal pulse rate (MPR) under the initial Partusisten infusion and the treatment with the two fenoterol test preparations.

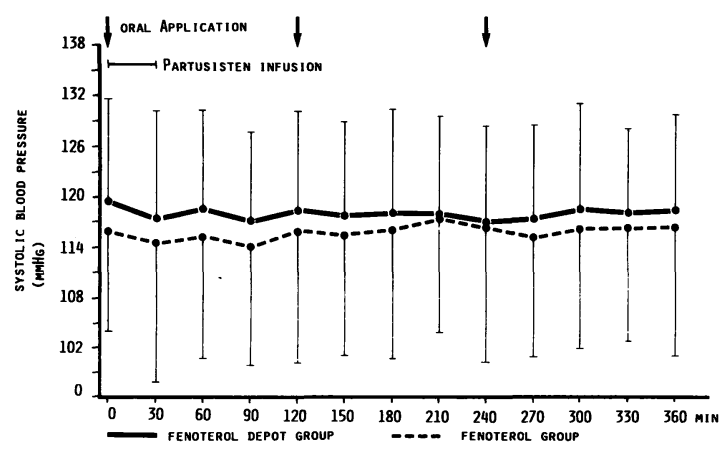

Figure 5. Behavior of maternal systolic blood pressure under the initial Partusisten infusion and the treatment with the two fenoterol test preparations.

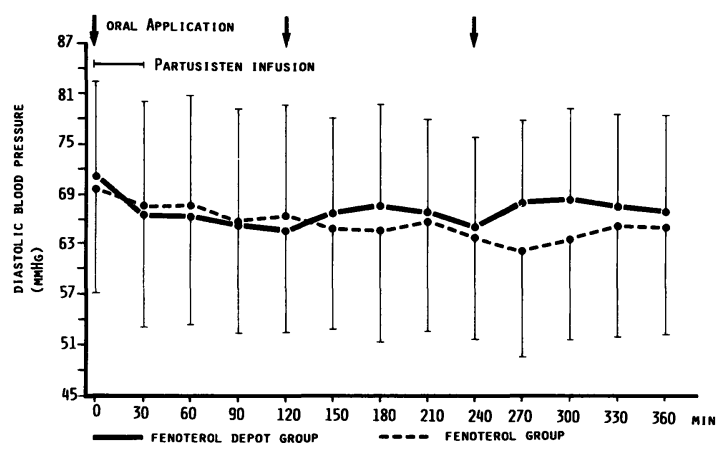

Figure 6. Behavior of maternal diastolic blood pressure under the initial Partusisten infusion and the treatment with the two fenoterol test preparations. 
Fetal pulse rate (FPR): As in the maternal cardiovascular parameters described above, the mean FPR in the two groups also demonstrated an approximately parallel curve course with a slight tendency to rise (figure 7). In the fenoterol depot group, the FPR before the beginning of infusion was 147.8 beats/min, and rose to 148.5 beats/min up to the end of infusion, and afterwards rose to 159.1 beats $/ \mathrm{min} 210 \mathrm{~min}$ later. The FPR was 158.1 beats/min at the end of the investigation. In the fenoterol group, it rose to 151.7 beats $/ \mathrm{min}$ at the end of the 30 minute Partusisten infusion (pretrial value 146.3 beats $/ \mathrm{min}$ ). At the end of the investigation, it rose to 160.3 beats/min with a maximum mean value of 160.8 beats $/ \mathrm{min} 300 \mathrm{~min}$ after the end of infusion. There was no statistically significant difference between the two groups for all measurement times.

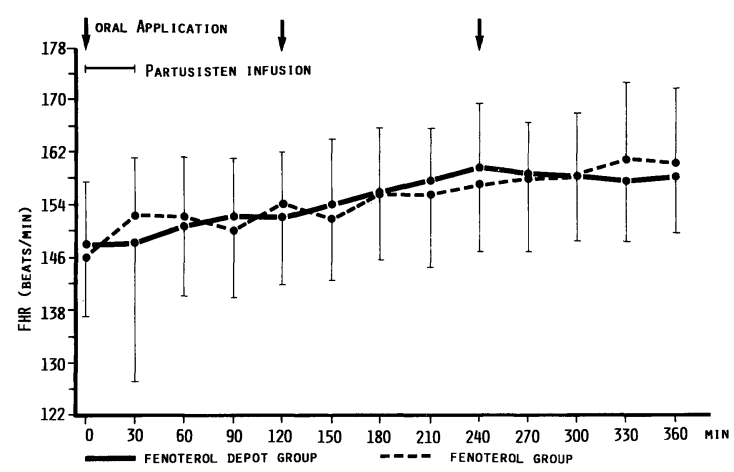

Figure 7. Behavior of the fetal pulse rate (FPR) under the initial Partusisten infusion and treatment with the two fenoterol test preparations.

\subsection{Tocolytic efficacy}

In $42(70 \%)$ of 60 patients in the fenoterol depot group and in $40(69 \%)$ of the 58 patients in the fenoterol group, the tocolytic efficacy was rated as "good", in 14 and 15 respectively as "satisfactory" and in four and three respectively as "not satisfactory". There was no statistically significant difference between the two groups.

\subsection{Tolerance}

In 45 patients $(75 \%)$ of the fenoterol depot group and 42 patients $(71 \%)$ of the fenoterol group, a good tolerance and in 12 and 14 patients respectively a satisfactory tolerance was recorded. In three patients in each of the two groups, the tolerance was designated as not satisfactory. A statistically significant difference could not be found between the two groups.

\subsection{Side effects}

In the fenoterol depot group, side effects were observed in 17 out of 66 patients $(26 \%)$ and in the fenoterol group in 20 out of 54 patients $(31 \%)$ (table II). Cardiovascular symptoms and tremor were unequivocally most prominent in the two groups. The total number of side effects reported is greater than that of the patients, since several side effects often occurred in one and the same patient.

Table II. Side effects of the two fenoterol preparations with delayed and undelayed release of substance and frequency of the occurrence in the course of the investigation.

\begin{tabular}{lll}
$\begin{array}{l}\text { Nature of } \\
\text { side effects }\end{array}$ & \multicolumn{2}{l}{ Frequency of side effects } \\
\cline { 2 - 3 } & $\begin{array}{l}\text { fenoterol } \\
\text { depot group } \\
\mathrm{n}=66\end{array}$ & $\begin{array}{l}\text { fenoterol } \\
\text { group } \\
\mathrm{n}=65\end{array}$ \\
\hline Subjective cardiovascular & 8 & 10 \\
Maternal tachycardia & 8 & 5 \\
Tremor & 7 & 7 \\
Restlessness & - & 2 \\
Slight dyspnea & 2 & 1 \\
Vertigo & - & 1 \\
Feeling of hotness & 2 & 3 \\
Visual disorders & & 1 \\
$\quad$ Mouches volantes) & - & 2 \\
Headache & 1 & 3 \\
Fetal tachycardia & - & 1 \\
Hypotension & - & - \\
Difficulty in breathing & 1 & - \\
Vomiting & 1 & - \\
Lassitude & 1 & \\
\hline
\end{tabular}




\section{Discussion}

A comparison of the tocolytic properties of the two preparations showed that both the single oral dose of fenoterol depot and three separate doses of fenoterol resulted in maintenance of constancy of the parameters associated with uterine contractions attained by partusisten infusion at a low level over a period of six hours. Fenoterol depot was equivalent or indeed slightly superior to fenoterol in this respect at some measurement times. Comparably good tocolytic effects with a fenoterol depot preparation have been observed by other authors [8].

It may be assumed that this effect is attributable to the action of the oral therapy alone, since a relevant influence of the I. V. treatment persisting beyond the duration of the infusion is hardly to be expected because of the short fenoterol halflife of 22 minutes.

The first oral dose of the two preparations was made for both groups at the same time, about 30 minutes before the end of the infusion, as has been recommended for a long time by various authors $[6,10,121,13,14]$. As with the initial Partusisten infusion, this oral administration served to produce comparable initial conditions, since it could not have any significant effect on the reduction of uterine contractions during the remaining period of infusion. The same amount of active substances was released without delay in both fenoterol preparations.

The tolerance of the fenoterol depot group proved to be equally, good, if not indeed somewhat better than fenoterol, which correlates well with results of other investigators [8]. An evaluation of the duration of the contractions of the basis of an external tocogram appeared to us to be justifiable, since in each patient the CTG was continuously plotted over the entire observation period, and the study thus involved a longitudinal comparison in relation to the respective pretrial value. With regard to the extrauterine effects (MPR, FPR, blood pressure), these showed equal or smaller variations in the fenoterol depot group than in the fenoterol group. Similar results have also been reported earlier $[2,11]$. In the side effects, which were slightly less in the fenoterol depot group than in the fenoterol group, cardiovascular symptoms and tremor were the most prominent. These are also to be expected in betamimetic therapy [10]. On the basis of this investigation as well as earlier studies [2, 8, 11], it can be observed overall that the present results on the fenoterol depot preparation encourage its clinical application.

\section{Summary}

In a double-blind randomized study, the effect of a single dose of a fenoterol preparation with delayed release of active substance (designated as fenoterol depot) was compared with a fenoterol product with undelayed release of active substance (designated as fenoterol) in two groups respectively comprising 66 and 65 female patients with premature uterine contractions.

The fenoterol depot was administered p.o. in a single total dose of $21 \mathrm{mg}$ at the beginning of an investigation period of 360 minutes and the fenoterol was administered p. o. within 235 minutes in three identical consecutive doses resulting in a total dose of $22.5 \mathrm{mg}$.

The increased uterine activity present at the beginning was markedly lowered by an initial intravenous infusion of Partusisten. After administration of the two oral preparations, the uterine contractions remainded at the low level achieved.

The fenoterol depot was slightly superior to fenoterol with regard to the reduction of the duration of contractions: the difference in the inhibition of the duration of the contraction between the two preparations was a maximum of $25.7 \%$ in favor of fenoterol depot. The frequency of uterine contraction was substantially reduced by both preparations, but to a greater extent by the depot form. The tocolytic efficacy and the tolerance were rated as "good" in $70 \%$ and $75 \%$ respectively with fenoterol depot and in $69 \%$ and in $71 \%$ respectively in the case of fenoterol. The maternal pulse rate remained at the level reached at the end of Partusisten infusion with the two preparation, and the blood pressure fluctuated slightly within the normal range. The fetal pulse rate demonstrated a slight rise within the normal range in the two groups. In the two groups of patients, there were occasional side effects (most prominently cardiovascular symptoms and tremor). The rate of side effects was somewhat less under fenoterol depot.

Keywords: Prematurity, tocolytic agent, uterine contractions. 


\section{Zusammenfassung}

Fenoterol-Depot und Fenoterol bei vorzeitiger Wehentätigkeit - eine multizentrische Doppelblindstudie im Vergleich

In einer doppelblinden, randomisierten Studie wurde die einmalige Gabe eines Fenoterol-Präparates mit verzögerter Wirkstoff-Freigabe (Fenoterol-Depot) mit einem Fenoterol-Präparat mit unverzögerter Wirkstoff-Freigabe (Fenoterol) an zwei Kollektiven von 66 bzw. 65 Patientinnen mit vorzeitiger Wehentätigkeit verglichen. Das Fenoterol-Depot wurde in einer einmaligen Gesamtdosis von $21 \mathrm{mg}$ am Anfang eines Untersuchungszeitraums von 360 Minuten und das Fenoterol innerhalb von 235 Minuten in drei identischen konsekutiven Gaben in einer Gesamtdosis von $22,5 \mathrm{mg}$ oral verabreicht. Die anfänglich bestehende, wesentlich erhöhte uterine Aktivität wurde durch eine initiale intravenöse Partusisten-Infusion deutlich gesenkt. Nach Gabe beider oraler Präparate blieb die Wehentätigkeit auf dem erreichten niedrigen Niveau.
Das Fenoterol-Depot war hinsichtlich der Reduktion der Kontraktionsdauer dem Fenoterol leicht überlegen: der Unterschied in der Hemmung der Kontraktionsdauer zwischen den beiden Präparaten betrug im Maximum $25,7 \%$ zugunsten des Fenoterol-Depots. Die Wehenfrequenz wurde mit beiden Präparaten maßgeblich, mit der Depot-Form jedoch ausgeprägter reduziert. Die tokolytische Wirksamkeit und die Verträglichkeit wurden bei Fenoterol-Depot zu 70 bzw. $75 \%$ und beim Fenoterol zu 69 bzw. 71\% mit "gut" beurteilt. Die mütterliche Herzfrequenz verblieb bei beiden Präparaten auf dem am Ende der Partusisten-Infusion erreichten Niveau, der Blutdruck schwankte geringfügig innerhalb des Normbereichs. Die fetale Herzfrequenz zeigte bei beiden Kollektiven einen im Normbereich liegenden geringen Anstieg. In beiden Patientinnen-Kollektiven traten vereinzelt Nebenwirkungen auf (vordergründig kardiovaskuläre Symptóme und Tremor), wobei unter dem Fenoterol-Depot die Nebenwirkungsrate etwas geringer ausfiel.

Schlüsselwörter: Frühgeburtlichkeit, Tokolytikum, Wehentätigkeit.

\section{Résumé}

Fenoterol et fenoterol retard en cas de contractions utérines prématurées - une étude comparative en double aveugle multicentrique

On a comparé dans une étude randomisée en double aveugle, l'effet d'une dose unique de fenoterol à action retard (fenoterol retard), à l'effet de fenoterol sans libération retardée (fenoterol) dans deux groupes comprenant respectivement 66 et 65 patientes présentant prématurément des contractions utérines.

Le fenoterol retard a été administré per os à dose unique de $21 \mathrm{mg}$ au début de la pèriode d'exploration de 360 minutes, et le fenoterol per os en trois doses consécutives identiques pendant 235 minutes à la dose totale de 22,5 mg. Une perfusion intra-veineuse initiale de Partusisten a nettement diminué l'activité utérine notablement augmentée au début. Après administration des deux préparations par voie orale, les contractions utérines sont demeurées au faible niveau obtenu.

Le fenoterol retard est légèrement supérieur au fenoterol pour la diminution de la durée des contractions: la différence dans l'inhibition de la durée des contractions entre les deux préparations est au maximum de $25,7 \%$ en faveur du fenoterol retard. La fréquence des contractions utérines est notablement diminuée par les deux préparations, mais plus par la forme retard. L'efficacité tocolytique et la tolérance sont notées comme «bonnes» dans respectivement $70 \%$ et $75 \%$ avec le fenoterol retard et dans respectivement $69 \%$ et $71 \%$ avec le fenoterol. Le pouls maternel est demeuré au même niveau que celui obtenu à la fin de la perfusion de Partusisten, avec les deux préparations, et la pression artérielle a légèrement varié dans les limites normales. Le rythme cardiaque fotal a montré une légère accélération à l'intérieur des limites normales, dans les deux groupes. Dans les deux groupes de patientes, il y a eu quelques effets secondaires (le plus souvent symptomes cardio-vasculaires et tremblements). La fréquence des effets secondaires a été moindre avec le fenoterol retard.

Mots-clés: Agents tocolytiques, contractions utérines, prématurité. 


\section{References}

[1] Bishop EH, TB Wouterss::" Arrest of premature labour. J Am Med Wom Assoc: 178 (1961) 812

[2] Fendel H, M Fendel, H Jung: Comparative investigations into oral tocolytic therapy with Fenoterol tablets and perlongets. In: JUNG H, G LAMBERTI (eds): Betamimetic drugs in obstetrics and perinatology, p 84. Thieme Verlag, Stuttgart 1982

[3] Frederick J, ABM ANDERson: Factors associated with spontaneous preterm birth. Br J Obstet Gynaecol 83 (1976) 342

[4] Grosspietsch G, M Fenske, B Dietrich, FBM ENSINK, M HöLZL, W KUHN: Effects of the tocolytic agent fenoterol on body weight, urine excretion, blood hemătocrit, hemoglobin, serum protein, and electrolyte levels in non-pregnant rabbits. Am J Obstet Gynecol 143 (1982) 667

[5] Jung H: Die Frühgeburz. In: KäsER O, V FrIEDBERG (eds): Schwangerschaft und Geburt 2, Bd. II/ 2, pp 9. Thieme Verlag, Stuttgart-New York 1981

[6] KoEPKE E, G SeIDENSCHNUR: Indikationen und Ergebnisse der Uterustokolyse. Zentralbl Gynakol 96 (1974) 193

[7] LAU H: Frühgeburt, Frühreife, Unreife. In: SChWALM H, G DöDERLEIN, KH Wulf (eds): Klinik der Frauenheilkunde und Geburtshilfe, Bd. I, p 415. Urban \& Schwarzenberg, Munich 1975

[8] Rausch K, M Hermer, H Brehm, V Edwabny, N LANG: Ein neues, langwirkendes Partusisten-Präparat zur oralen Tokolyse - Ergebnisse einer multizentrischen Studie. Z Geburtshilfe Perinatol 188 (1084) 185

[9] RICHTER R: Langzeittokolyse mit Betamimetika zur Behandlung der drohenden Frühgeburt. Ther Umsch 35 (1978) 410
[10] Richter R, MJ HinselmanN: The treatment of threatened premature labour by betamimetic drugs: A comparison of fenoterol and ritodrine. J Obstet Gynecol 53 (1979) 81

[11] Schuhmann R, E Halberstadt, R Gerner: Double-blind study on the efficacy of fenoterol. In: JUNG H, G LAMBERTI (eds): Beta-mimetic drugs in obstetrics and perinatology, p 87. Thieme Verlag, Stuttgart 1982

[12] WeIDINGer H, W WIEST: Die Behandlung des Spätaborts und der drohenden Frühgeburt mit Th 1165 a in Kombination mit Isoptin ${ }^{\circledR}$. Z Geburtshilfe Perinatol 177 (1973) 233

[13] Weidinger H: Orale Tokolyse - jetzt besserer Therapieerfolg durch veränderte Galenik (Tagungsbericht). Gemeinsame Tagung der Österreichischen Gesellschaft für Gynäkologie und Geburtshilfe und der Bayerischen Gesellschaft für Geburtshilfe und Frauenheilkunde in Graz, 14th-16th June 1976. Geburtshilfe Frauenheilkunde 40 (1980) 288

[14] WeIDINGER H: Übersicht über verschiedene bei der Tokolyse eingesetzte Substanzen. In: IRMER M, H WeIDINGER (eds): Neuere Aspekte zu Betablockade und Tokolyse. Beltz Verlag, Weinheim/Baden 1983

Received October 25, 1985. Revised March 14, 1986. Accepted March 26, 1986.

Priv.-Doz. Dr. W. Müller-Holve

Klinikum Ingolstadt

Krumenauer Str. 25

D-8070 Ingolstadt, West Germany 